\title{
Mismatch Repair Protein Deficiency Is a Risk Factor for Aberrant Expression of HLA Class I Molecules: A Putative "Adaptive Immune Escape" Phenomenon
}

\author{
TERUFUMI KUBO ${ }^{1}$, YOSHIHIKO HIROHASHI ${ }^{1}$, KAZUHIKO MATSUO ${ }^{2}$, TOMOKO SONODA ${ }^{3}$, \\ HIROKI SAKAMOTO ${ }^{2}$, KIYOSHI FURUMURA ${ }^{2}$, TOMOHIDE TSUKAHARA ${ }^{1}$, TAKAYUKI KANASEKI ${ }^{1}$, \\ MUNEHIDE NAKATSUGAWA ${ }^{1}$, HIROSHI HIRANO ${ }^{4}$, TOMOHISA FURUHATA ${ }^{5}$, \\ ICHIRO TAKEMASA ${ }^{5}$, TADASHI HASEGAWA ${ }^{4}$ and TOSHIHIKO TORIGOE ${ }^{1}$ \\ Departments of ${ }^{1}$ Pathology, ${ }^{3}$ Public Health, ${ }^{4}$ Surgical Pathology, and \\ ${ }^{5}$ Surgical Oncology and Science, Sapporo Medical University, School of Medicine, Sapporo, Japan; \\ ${ }^{2}$ Sapporo Clinical Laboratory Inc., Sapporo, Japan
}

\begin{abstract}
Accumulating evidence indicates that immune checkpoint inhibition-mediated cancer immunotherapies greatly improve the prognosis of certain types of cancer. This approach is now becoming a standard therapy, joining surgery, radiotherapy, and chemotherapy. Because the costs of antibody drugs are now a socioeconomic burden in many countries, an urgent need in cancer immunotherapy is the identification of relevant biomarkers that can predict therapy efficacy. Recent studies have reported that colorectal adenocarcinoma with hereditary or sporadic deficiency in mismatch repair (MMR) proteins has high antigenicity and that detection of these proteins could be a promising way to estimate clinical response. In this study of 135 patients with colorectal cancer, we used immunohistochemistry to investigate the correlation between deficiency in MMR proteins and expression of human leukocyte antigen (HLA) class I molecules, a prerequisite of cytotoxic T-cell-based immunotherapy. Interestingly, MMR protein deficiency was an independent risk factor for the impaired expression of HLA class I molecules (odds ratio $(O R)=10.44,95 \%$ confidence interval $(C I)=3.15-34.62, p<0.001)$, suggesting the existence of a putative entity that we have named
\end{abstract}

This article is freely accessible online.

Correspondence to: Terufumi Kubo, MD, Ph.D. or Yoshihiko Hirohashi, MD, Ph.D., Department of Pathology, Sapporo Medical University, School of Medicine, South 1, West 17, Chuo-ku, Sapporo, Hokkaido 060-8556, Japan. Tel: +81 0116112111, Fax: +810116432310, e-mail: kuboteru@sapmed.ac.jp (T. Kubo) or hirohash@sapmed.ac.jp (Y. Hirohashi)

Key Words: Adenocarcinoma of the colon, cancer immunotherapy, HLA class I molecules, immune escape, mismatch repair proteins. "adaptive immune escape". Moreover, our results might provide a potential novel biomarker for the selection of patients who would respond to cancer immunotherapies. At the same time, the results suggest that we have to overcome the impaired expression of HLA class I molecules to further improve the cure rate of cancer immunotherapies.

In the past 100 years, oncologists and immunologists have extensively investigated how to overcome malignant tumors by using autologous immune therapy. Since the epoch-making discovery of melanoma-specific antigen, there has been no doubt that CD8-positive cytotoxic T-lymphocytes (CTLs) suppress established malignancies (1). Nevertheless, several decades elapsed before immunotherapy was established as a standard treatment because a number of clinical trials fell short of expectations and failed to show significant effects. The hopes of researchers are now becoming realized as recently approved immune checkpoint inhibitors, namely of programmed cell death-1 (PD-1) and CTL-associated antigen4, achieve an even better prognosis than existing chemotherapy in patients with certain types of malignant tumors, including melanoma and non-small cell lung cancer (2-4). Nonetheless, the current response rate of tumors to these medications is still unsatisfactory. To make matters worse, these antibody drugs are expensive and are thus becoming a socioeconomic burden. Therefore, biomarkers that can determine whether a specific drug would be effective or not in an individual patient are urgently required.

Various types of cancers, including colorectal, endometrial, and ovarian, show hereditary or sporadic loss of mismatch repair (MMR) proteins (5). Patients with an MMR protein deficiency can be identified using immunohistochemistry (IHC) for MutL protein homolog 1 (MLH1), MutS protein homolog 2 (MSH2), MutS protein homolog 6 (MSH6), and 
postmeiotic segregation increased 2 (PMS2) or polymerase chain reaction for microsatellite instability (6). Currently, patients with colorectal adenocarcinoma with loss of these MMR proteins are suggested to be promising candidates for the application of targeted immune checkpoint inhibition therapy, presumably because deficiencies in these proteins lead to frequent generation of neo-antigens, which can have high antigenicity $(7,8)$. The crucial event of cancer immunotherapy is the recognition by the T-cell receptor on CD8-positive CTLs of the antigen presented on the human leukocyte antigen (HLA) class I complex of tumor cells (9). However, tumor cells eventually block the attack of CD8positive CTLs by expressing immune checkpoint molecules such as PD-L1 or by down-regulating HLA class I molecules on the cell surface. The former mechanism of immune resistance is resolved, at least partly, by immune checkpoint inhibitors. On the other hand, the immune escape mediated by the loss of HLA class I molecules is a considerable hindrance to current and potentially future cancer immunotherapies.

In this study, we performed IHC for MMR proteins and HLA class I molecules in samples from 135 patients with colorectal adenocarcinoma.

\section{Materials and Methods}

Patients and specimens. Surgical specimens were obtained from 135 patients who underwent surgery for primary colon or rectum adenocarcinoma at the Department of Surgery, Surgical Oncology and Science of Sapporo Medical University Hospital, Sapporo, Japan. Written informed consent was obtained from each patient according to the guidelines of the Declaration of Helsinki. This research was approved by the Institutional Review Board of Sapporo Medical University Hospital under permit number 282-1038. Clinicopathological factors are summarized in Table I. Tumor tissues were fixed in $10 \%$ buffered formalin and embedded in paraffin. The diagnosis was confirmed in accordance with the seventh edition of the TNM Classification of Malignant Tumors (10).

Immunohistochemical staining. Sections (4- $\mu$ m thick) of formalinfixed, paraffin-embedded, tumors were immunostained using monoclonal antibodies after epitope retrieval by Target Retrieval Solution pH 9 (DAKO, Glostrup, Denmark). To detect MMR protein in tumor cells, rabbit anti-MSH6 monoclonal antibody (clone EP51; DAKO) and mouse anti-PMS2 monoclonal antibody (clone ES05; DAKO) were used at the concentrations described in the manufacturer's instructions. Mouse anti-HLA class I molecule (clone EMR8-5; commercially available from Hokudo Co. Ltd, Sapporo, Japan) was previously generated in our laboratory and was used at $0.5 \mu \mathrm{g} / \mathrm{ml}$ (11). Subsequent incubation with a secondary antibody was performed. Slides were counterstained with hematoxylin, rinsed, dehydrated in a graded ethanol series, and then coverslipped with mounting media. To obtain concordant immunohistochemical results, each slide was examined on a multiheaded microscope by three pathologists. The staining of all tissue samples was verified by comparison with an internal positive control. To evaluate the expression of MSH6 and PMS2, germinal center lymphocytes or non-tumorous glands in each specimen were
Table I. Clinicopathological factors of the 135 patients with colorectal adenocarcinoma included in this study.

\begin{tabular}{lc}
\hline Characteristic & Value \\
\hline Age (years) & \\
Mean \pm SD & $65.0 \pm 10.4$ \\
Range & $2-84$ \\
Gender, $\mathrm{n}(\%)$ & \\
Male & $69(51.1)$ \\
Female & $66(48.9)$ \\
Region, $\mathrm{n}(\%)$ & \\
Cecum & $13(9.6)$ \\
Ascending & $26(19.3)$ \\
Transverse & $15(11.1)$ \\
Descending & $9(6.7)$ \\
Sigmoid & $50(37.0)$ \\
Rectum & $22(16.3)$ \\
T-Stage, $\mathrm{n}(\%)$ & \\
T1 & $4(3.0)$ \\
T2 & $17(12.6)$ \\
T3 & $99(73.3)$ \\
T4a & $7(5.2)$ \\
T4b & $8(5.9)$ \\
Lymph-node metastasis, $\mathrm{n}(\%)$ & \\
Positive & $120(88.9)$ \\
Negative & $14(11.1)$ \\
Histopathologic grade, $\mathrm{n}(\%)$ & \\
Well-differentiated & $53(39.3)$ \\
Moderately differentiated & $73(54.1)$ \\
Mucinous & $6(4.4)$ \\
Poorly differentiated & $3(2.2)$ \\
\hline
\end{tabular}

designated as the internal positive control. More than $10 \%$ nuclear staining in tumor cells for these proteins was defined as positive staining. Infiltrating inflammatory cells in tumor tissue were designated as internal positive control for HLA class I molecules.

Statistical analysis. Statistical analyses were performed with SPSS (version 24 for Windows; IBM, Armonk, NY, USA) and GraphPad Prism (Version 6.0 for Windows; GraphPad Software Inc., San Diego, CA, USA). Pearson Chi-square tests were used to determine the significance of associations between characteristic variables. A logistic regression model was used for multivariate analysis to predict the odds ratio of individual factors for loss of cell surface HLA class I molecules. Each multivariate analysis was performed with the stepwise method. In all analyses, a value of $p<0.05$ was considered statistically significant.

\section{Results}

MMR protein deficiency. To investigate the levels of MMR proteins, we performed IHC staining in resected colorectal adenocarcinoma samples from 135 patients. Although four main proteins, namely MLH1, MSH2, MSH6, and PMS2, exhibit deficiencies in adenocarcinoma of the colon, detection of MSH6 and PMS2, that we performed here, can 
reflect the loss of all of these proteins. This is because MSH6 and PMS2 stability is dependent on MSH2 and MLH1, respectively. Of the 135 patients, 118 (87.4\%) showed intact nuclear expression of both MSH6 and PMS2 (Figure 1A). In contrast, lack of MSH6 or PMS2 was found in seven (5.2\%) and $11(8.1 \%)$ patients, respectively. One patient had loss of both MSH6 and PMS2. Taken together, 17 out of the 135 patients with colorectal adenocarcinoma (12.6\%) had defects in MMR protein. This rate is consistent with that of previous work (6).

HLA class I expression. Because $\mathrm{HC} 10$, an antibody previously used to detect HLA class I molecules, can detect HLA-B and - $\mathrm{Cw}$ but not $-\mathrm{A}$, it cannot accurately reveal the loss of expression of HLA class I molecules (9). We recently developed an anti-HLA class I molecule monoclonal antibody (EMR8-5) that can detect all three classical types of HLA class I molecules, namely, HLA-A, -B, and -Cw. Therefore, the EMR8-5 antibody can detect the loss of HLA class I molecule expression (11).

IHC staining was performed to determine the expression of HLA class I molecules in colorectal adenocarcinoma. The tumor cells showed three staining patterns. The first pattern was that of intact expression, which consists of HLA class I molecules on the cell surface (Figure 2A, left panel). The second pattern is the cytoplasmic pattern, which supposedly reflects intracellular HLA class I molecules (Figure 2A, center panel). The third pattern is a lack of signal in the cells (Figure 2A, right panel), suggesting the loss of HLA class I molecule expression. Because functional HLA class I molecule must be located on the cell surface for antigen peptide presentation, we those with cytoplasmic and those with absent signal patterns into a single group representing specimens with a loss of cell surface HLA class I molecules. We then graded the proportions of each staining pattern of the HLA class I molecules. Although 31 out of the 135 tumor specimens (23.0\%) showed retained cell surface HLA class I molecules in all fields of view, 10 out of the 135 specimens (7.4\%) had no cell surface HLA class I molecules. The other specimens (94 out of the 135 patients; $69.6 \%$ ) had a heterogeneous staining pattern (Figure 2B). Interestingly, a sudden transition of the staining pattern was often observed in the tumor cells (Figure 2C).

Correlation between MMR protein deficiencies and loss of cell surface HLA class I molecule. We investigated which pattern of HLA class I molecule staining predominated in each patient with colorectal adenocarcinoma. As shown in Table II, 94 out of the 135 specimens $(69.6 \%)$ largely consisted of adenocarcinoma cells with intact staining of HLA class I molecules. On the other hand, 41 out of the 135 cases $(30.4 \%)$ revealed the predominant loss of the cell surface expression of HLA class I molecules. Interestingly,
A

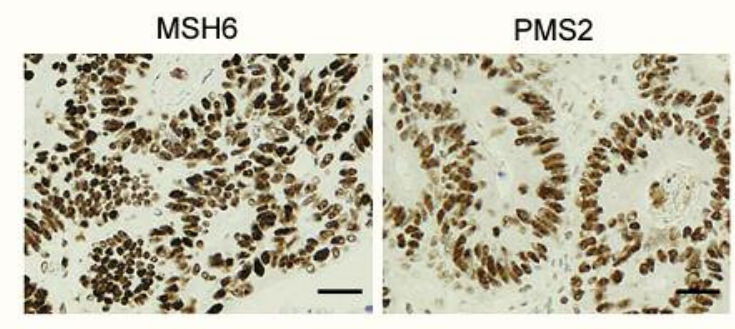

B

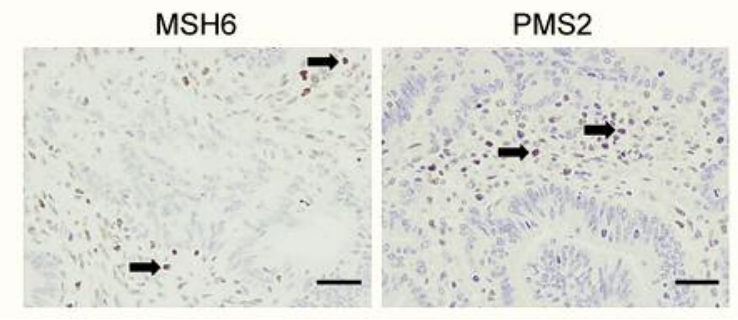

Figure 1. Immunohistochemistry for MutS protein homolog 6 (MSH6) and postmeiotic segregation increased 2 (PMS2) in colorectal adenocarcinoma. A: Intact nuclear staining pattern. B: Loss of staining, indicating a mismatch repair protein deficiency. The staining was verified by comparison with the internal positive control. Note that some infiltrating mononuclear cells exhibit nuclear staining (arrows). Bar=50 um. Original magnification: $\times 100$.

there was a significant correlation of MMR protein deficiencies with poorly differentiated histopathological grade and a loss of cell surface HLA class I molecules $(p<0.001$ and $p<0.05$, respectively). None of the other factors investigated in this study were correlated with the expression pattern of HLA class I molecules.

Table III shows the results of univariate analysis with logistic regression of risk factors for loss of leukocyte antigen (HLA) class I molecule expression. Only loss of mismatch repair protein expression was found to be a significant factor. Multivariate logistic regression model was used for further analysis and showed MMR protein deficiency was correlated with a loss of cell surface HLA class I molecules independently of other clinical characteristics (odds ratio $=10.44,95 \%$ confidence interval $=3.15-34.62, p<0.001$ ). Although there was a significant correlation between poorly differentiated histopathological grade and loss of cell surface HLA class I molecules, this association was excluded from the analysis because there were insufficient numbers of patients with poorly differentiated adenocarcinoma in the study population.

\section{Discussion}

Accumulating evidence suggests that colorectal cancer with hereditary or sporadic deficiency in MMR proteins has better 
A

\section{Cell surface}

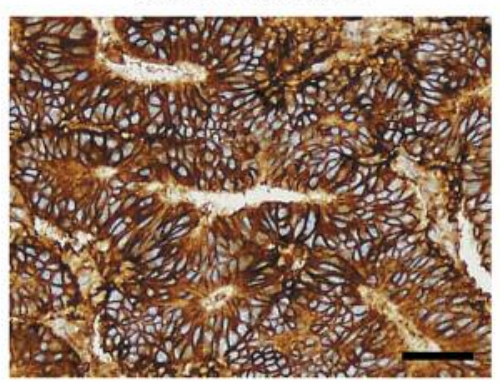

\section{HLA class I (EMR8-5)}

Cytoplasm

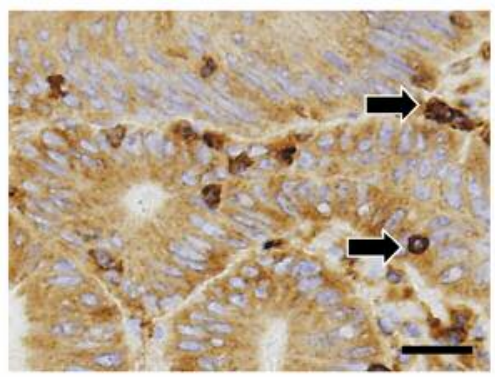

\section{Loss}

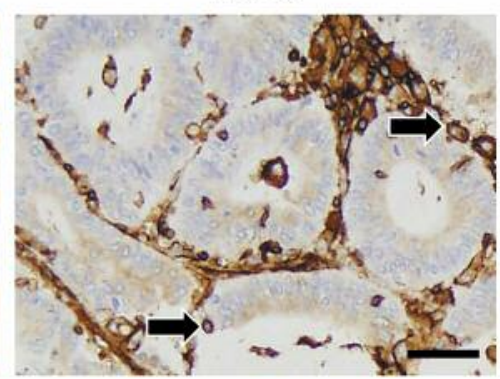

B

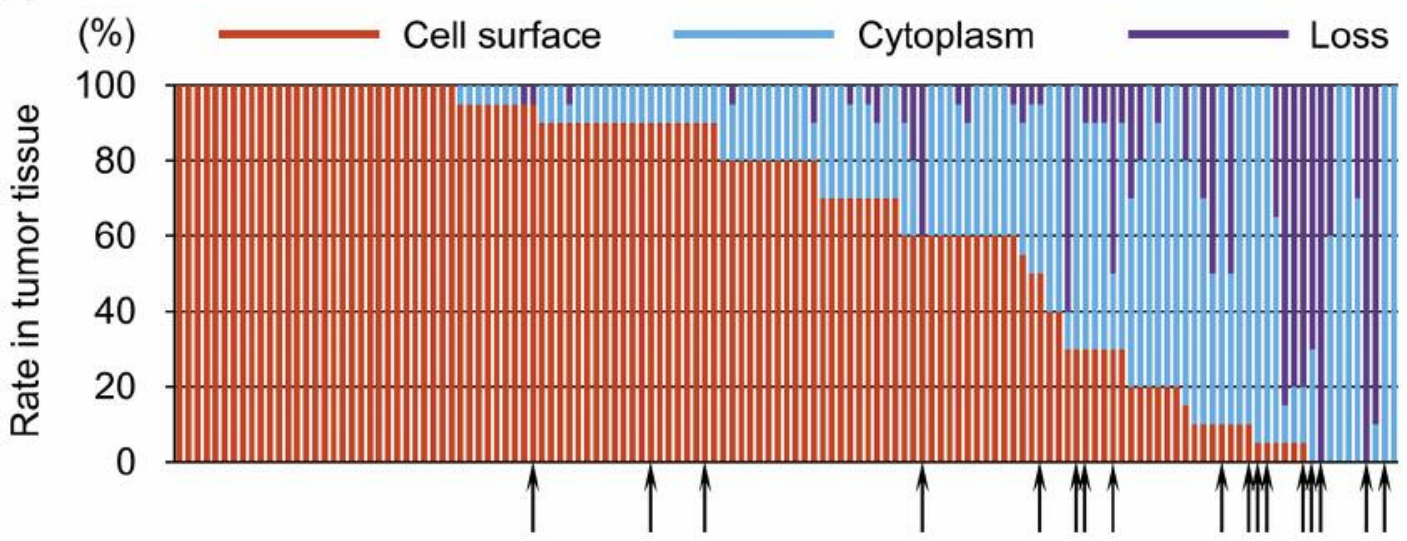

C

\section{HLA class I (EMR8-5)}

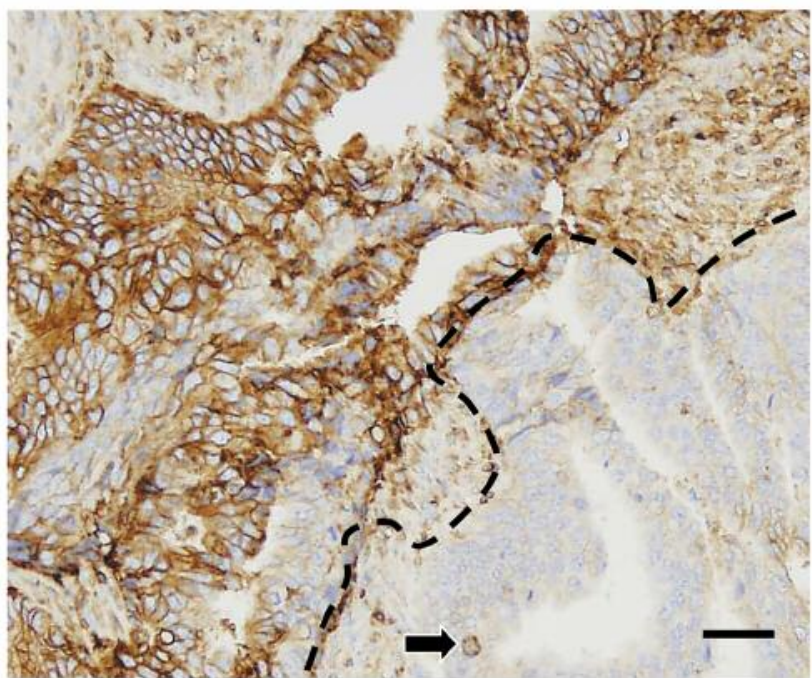

Figure 2. Expression pattern of human leukocyte antigen (HLA) class I molecules detected by the EMR8-5 monoclonal antibody. A: Three staining patterns are shown. Left panel: Intact cell boundary staining; center panel: cytoplasmic staining; right panel: no staining. Non-tumor cells were considered internal positive controls. Note that some infiltrating mononuclear cells and interstitial cells exhibit cell boundary staining when tumor cells exhibited cytoplasmic staining or loss of staining (arrows). Bar=50 $\mu \mathrm{m}$. Original magnification: $\times 100$. B: Frequency distribution data of the staining patterns. Arrows indicate the specimens with a mismatch repair protein deficiency. Red: Cell surface pattern; light blue: cytoplasmic pattern; blue: loss of staining. $C$ : Sudden transition of the staining pattern of HLA class I molecules. The dotted line separates the intact cell boundary staining (left) from the absence of staining. An arrow indicates staining of intact HLA class I molecule of an infiltrating inflammatory cell. Bar=50 $\mu$ m. Original magnification: $\times 100$. 
Table II. Association of human leukocyte antigen (HLA) class I molecule expression with clinicopathologic features and mismatch repair (MMR) protein expression in colorectal adenocarcinoma.

\begin{tabular}{|c|c|c|c|}
\hline \multirow[t]{2}{*}{ Characteristic } & \multicolumn{2}{|c|}{ HLA class I expression } & \multirow[t]{2}{*}{$p$-Value } \\
\hline & $\begin{array}{l}\text { Intact } \\
(\mathrm{n}=94)\end{array}$ & $\begin{array}{l}\text { Loss } \\
(\mathrm{n}=41)\end{array}$ & \\
\hline \multicolumn{4}{|l|}{ Age, years } \\
\hline Mean \pm SD & $65.7 \pm 11.3$ & $63.3 \pm 10.5$ & \\
\hline Range & $22-82$ & $41-84$ & \\
\hline \multicolumn{4}{|l|}{ Gender, n $(\%)$} \\
\hline Male & $48(51.1)$ & $21(51.2)$ & 0.99 \\
\hline Female & $46(48.9)$ & $20(48.8)$ & \\
\hline \multicolumn{4}{|l|}{ Region, n (\%) } \\
\hline Cecum & $9(9.6)$ & $4(9.8)$ & $1^{\dagger}$ \\
\hline Ascending & $18(19.1)$ & $8(19.5)$ & 0.96 \\
\hline Transverse & $11(11.7)$ & $4(9.8)$ & $0.74 \dagger$ \\
\hline Descending & $8(8.5)$ & $1(2.4)$ & $0.28 \dagger$ \\
\hline Sigmoid & $32(34.0)$ & $18(43.9)$ & 0.28 \\
\hline Rectum & $16(17.0)$ & $6(14.6)$ & 0.73 \\
\hline \multicolumn{4}{|l|}{ T-Stage } \\
\hline $\mathrm{T} 1$ & $2(2.1)$ & $2(4.9)$ & $0.23^{\dagger}$ \\
\hline $\mathrm{T} 2$ & $11(11.7)$ & $6(14.6)$ & \\
\hline $\mathrm{T} 3$ & $73(77.7)$ & $26(63.4)$ & \\
\hline $\mathrm{T} 4 \mathrm{a}$ & $5(5.3)$ & $2(4.9)$ & \\
\hline $\mathrm{T} 4 \mathrm{~b}$ & $3(3.2)$ & $5(12.2)$ & \\
\hline \multicolumn{4}{|l|}{ Lymph-node metastasis } \\
\hline Positive & $12(12.8)$ & $3(7.3)$ & $0.35^{\dagger}$ \\
\hline Negative & $82(87.2)$ & $38(92.7)$ & \\
\hline \multicolumn{4}{|l|}{ Histopathological grade, $\mathrm{n}(\%)$} \\
\hline Well-differentiated & $38(40.4)$ & $15(36.6)$ & 0.67 \\
\hline Moderately differentiated & $53(56.4)$ & $20(18.8)$ & 0.42 \\
\hline Mucinous & $3(3.2)$ & $3(7.3)$ & $0.28^{\dagger}$ \\
\hline Poorly differentiated & $0(0.0)$ & $3(7.3)$ & $0.027^{\dagger}$ \\
\hline \multicolumn{4}{|l|}{ MMR protein deficiency, $\mathrm{n}(\%)$} \\
\hline Intact & $90(95.7)$ & $28(68.3)$ & $<0.001$ \\
\hline Loss & $4(4.3)$ & $13(31.7)$ & \\
\hline
\end{tabular}

Patient characteristics were statistically analyzed using a Chi-square test. †Fisher's exact test was used for statistical analysis when there were fewer than five observations.

prognosis than cancer forms with intact expression of these proteins $(12,13)$. This association is because frequent DNA mutation due to impairment of the MMR machinery would promote the occasional generation of highly antigenic neoantigens that are targeted by CTLs (8). However, tumors with high antigenicity often change their phenotype in response to cytotoxic and pro-inflammatory immune responses by overexpressing immune suppressive molecules such as PD-L1 (14). This "adaptive immune resistance" is at least partly controlled by treatment with PD-1-blocking antibodies. In this study, we showed that colorectal adenocarcinomas with MMR protein deficiency frequently harbor impaired expression of membrane HLA class I
Table III. Univariate analysis with logistic regression analysis of risk factors for loss of leukocyte antigen (HLA) class I molecule expression.

\begin{tabular}{lcc}
\hline Factor & Univariate & $p$-Value \\
\hline OR (95\% CI) & \\
Advanced T-stage (T4) & $10.4(3.15-34.6)$ & $<0.001$ \\
Advanced age (>65 years) & $2.21(0.74-6.58)$ & 0.1455 \\
Region & $0.58(0.27-1.26)$ & 0.1504 \\
$\quad$ Cecum & $1.02(0.30-3.53)$ & \\
Ascending & $1.02(0.40-2.59)$ & 0.96 \\
Transverse & $0.82(0.24-2.73)$ & 0.74 \\
Descending & $0.27(0.03-2.22)$ & 0.28 \\
Sigmoid & $1.52(0.72-3.21)$ & 0.28 \\
$\quad$ Rectum & $0.84(0.30-2.31)$ & 0.73 \\
Positive for lymph node metastasis & $0.54(0.14-2.02)$ & 0.35 \\
Histopathological grade & & \\
$\quad$ Well-differentiated & $0.85(0.34-1.81)$ & 0.67 \\
$\quad$ Moderately differentiated & $0.74(0.35-1.54)$ & 0.42 \\
$\quad$ Mucinous & $2.40(0.46-12.41)$ & 0.36 \\
Poorly differentiated & - & - \\
\hline
\end{tabular}

95\% CI, 95\% Confidence interval; OR, odds ratio. In poorly differentiated adenocarcinoma, expression of HLA class I molecules was lost in all patients.

molecules, suggesting the existence of a putative entity that we have named "adaptive immune escape". It can be assumed that highly antigenic colon adenocarcinoma with loss of MMR protein expression is under active immune attack. Consequently, tumor components with impaired surface HLA class I molecules escape the immune system and predominantly survive. Although a significant correlation was found between poorly differentiated histopathological grade and loss of cell surface HLA class I molecules, we were unable to perform univariate or multivariate analysis of this due to an insufficient number of patients. MMR protein deficiency is often associated with a poorly differentiated histology (5). Therefore, it may not be an independent risk factor for loss of cell surface HLA class I molecules.

In our study, two patterns of surface HLA class I molecule deficiency were found, one involving cytoplasmic staining, the other involving loss of staining. Several mechanisms might explain the aberrant expression of HLA class I molecules: gene mutations or transcriptional impairment of HLA class I antigens subunits, failure of antigen-presenting machinery including the mutation of $\beta 2$-microgloblin, or proteasomal degradation of HLA class I molecules $(15,16)$. Together with the natural selection afforded by the immune attack, impaired expression of HLA class I molecules might be due to frequent mutation of HLA class I- or antigenpresenting machinery-related genes due to MMR protein deficiency. Previous reports have shown that loss or down- 
regulation of HLA class I molecules was an independent prognostic factor in malignant tumors including colorectal, renal, ovarian, bladder cancer, and osteosarcoma (17-20). Furthermore, mutation of the $\beta 2$-microgloblin gene was associated with resistance to immune checkpoint therapy (21). Because we did not clarify exactly how the membrane HLA class I molecule was lost, the mechanism should be investigated in future studies.

Recent advances in cancer immunotherapy based on inhibition of immune checkpoints have provided us with an additional strategy for cancer treatment. Nonetheless, other problems have been encountered, such as the need for research into biomarkers for estimating the clinical efficacy of the treatment. The fundamental mechanistic concept behind current cancer immunotherapy approaches is the recognition of the cancer antigen presented on HLA class I molecules by antigen-specific CD8-positive CTLs (9). Therefore, expression of HLA class I molecules should be a prerequisite for cancer immunotherapy. Indeed, our previous report showed that there was no effect of peptide vaccination-based immunotherapy on tumors lacking expression of HLA class I molecules (9). While MMRdeficient colorectal adenocarcinomas tend to have an excellent response to immune checkpoint inhibition therapy (7), these types of tumors frequently lack cell surface HLA class I molecules, as shown in this study. This finding implies that conventional IHC analysis of the expression of HLA class I molecules might be useful to refine indications or estimate the clinical efficacy of immunotherapy. Investigation of the correlation between the clinical efficacy of immune checkpoint inhibition therapy and the cell surface expression of HLA class I molecules should be performed in colorectal adenocarcinoma and other types of cancers with MMR protein deficiency.

Curiously, we often observed a sudden change in the staining pattern, suggesting that tumors with uniform morphology consisted of various clones with distinctive gene expressions. An additional important finding of this study is that more than $70 \%$ of cases contained a certain amount of tumor component without membrane HLA class I molecules. These tumor cells would evade CTL-based immune therapies and could trigger recurrence of cancer. Therefore, this problem, i.e. loss of HLA class I molecules, has to be overcome in order to improve the cancer immunotherapy approach.

In conclusion, we showed that loss of MMR proteins was an independent risk factor for impaired cell surface HLA class I expression in colorectal adenocarcinoma. This putative "adaptive immune escape" phenomenon suggests a potential impediment to existing and next-generation immunotherapies for malignant tumors. Further clinical and basic studies are required to surmount this issue.

\section{Conflicts of Interest}

K. Matsuo, H. Sakamoto and K. Furumura are employees of Sapporo Clinical Laboratory Inc. T. Torigoe received a research grant from Sapporo Clinical Laboratory Inc. The other Authors have no conflict of interest in regard to this study.

\section{Acknowledgements}

This work was supported by Grant-in-Aid for Scientific Research (B) of the Japan Society for the Promotion of Science (JSPS) for Y. Hirohashi (Grant Number 15H04722) and the Project for Cancer Research and Therapeutic Evolution (P-CREATE) from the Japan Agency for Medical Research and development (AMED) for T. Torigoe.

\section{References}

1 van der Bruggen $\mathrm{P}$, Traversari $\mathrm{C}$, Chomez $\mathrm{P}$, Lurquin $\mathrm{C}$, De Plaen E, Van den Eynde B, Knuth A and Boon T: A gene encoding an antigen recognized by cytolytic T-lymphocytes on a human melanoma. Science 254(5038): 1643-1647, 1991.

2 Borghaei H, Paz-Ares L, Horn L, Spigel DR, Steins M, Ready NE, Chow LQ, Vokes EE, Felip E, Holgado E, Barlesi F, Kohlhaufl M, Arrieta O, Burgio MA, Fayette J, Lena H, Poddubskaya E, Gerber DE, Gettinger SN, Rudin CM, Rizvi N, Crino L, Blumenschein GR Jr., Antonia SJ, Dorange C, Harbison $\mathrm{CT}$, Graf Finckenstein F and Brahmer JR: Nivolumab versus docetaxel in advanced nonsquamous non-small-cell lung cancer. N Engl J Med 373(17): 1627-1639, 2015.

3 Brahmer J, Reckamp KL, Baas P, Crino L, Eberhardt WE, Poddubskaya E, Antonia S, Pluzanski A, Vokes EE, Holgado E, Waterhouse D, Ready N, Gainor J, Aren Frontera O, Havel L, Steins M, Garassino MC, Aerts JG, Domine M, Paz-Ares L, Reck M, Baudelet C, Harbison CT, Lestini B and Spigel DR: Nivolumab versus docetaxel in advanced squamous-cell nonsmall-cell lung cancer. N Engl J Med 373(2): 123-135, 2015.

4 Robert C, Long GV, Brady B, Dutriaux C, Maio M, Mortier L, Hassel JC, Rutkowski P, McNeil C, Kalinka-Warzocha E, Savage KJ, Hernberg MM, Lebbe C, Charles J, Mihalcioiu C, Chiarion-Sileni V, Mauch C, Cognetti F, Arance A, Schmidt H, Schadendorf D, Gogas H, Lundgren-Eriksson L, Horak C, Sharkey B, Waxman IM, Atkinson V and Ascierto PA: Nivolumab in previously untreated melanoma without $B R A F$ mutation. N Engl J Med 372(4): 320-330, 2015.

5 Shia J, Holck S, Depetris G, Greenson JK and Klimstra DS: Lynch syndrome-associated neoplasms: A discussion on histopathology and immunohistochemistry. Fam Cancer 12(2): 241-260, 2013.

6 Samowitz WS: Evaluation of colorectal cancers for lynch syndrome: Practical molecular diagnostics for surgical pathologists. Mod Pathol 28(Suppl 1): S109-113, 2015.

7 Le DT, Uram JN, Wang H, Bartlett BR, Kemberling H, Eyring AD, Skora AD, Luber BS, Azad NS, Laheru D, Biedrzycki B, Donehower RC, Zaheer A, Fisher GA, Crocenzi TS, Lee JJ, Duffy SM, Goldberg RM, de la Chapelle A, Koshiji M, Bhaijee F, Huebner T, Hruban RH, Wood LD, Cuka N, Pardoll DM, Papadopoulos N, Kinzler KW, Zhou S, Cornish TC, Taube JM, Anders RA, Eshleman JR, Vogelstein B and Diaz LA Jr.: PD-1 
blockade in tumors with mismatch-repair deficiency. $\mathrm{N}$ Engl J Med 372(26): 2509-2520, 2015

8 Riaz N, Morris L, Havel JJ, Makarov V, Desrichard A and Chan TA: The role of neoantigens in response to immune checkpoint blockade. Int Immunol 28(8): 411-419, 2016.

9 Sato N, Hirohashi Y, Tsukahara T, Kikuchi T, Sahara H, Kamiguchi K, Ichimiya S, Tamura Y and Torigoe T: Molecular pathological approaches to human tumor immunology. Pathol Int 59(4): 205-217, 2009.

10 Sobin LH, Gospodarowicz MK, Wittekind C and International Union against Cancer: TNM Classification of Malignant Tumours. Seventh Edition. Wiley-Blackwell: Chichester, West Sussex, UK, 2010.

11 Torigoe T, Asanuma H, Nakazawa E, Tamura Y, Hirohashi Y, Yamamoto E, Kanaseki $\mathrm{T}$, Hasegawa $\mathrm{T}$ and Sato $\mathrm{N}$ : Establishment of a monoclonal anti-pan HLA class I antibody suitable for immunostaining of formalin-fixed tissue: Unusually high frequency of down-regulation in breast cancer tissues. Pathol Int 62(5): 303-308, 2012.

12 Popat S, Hubner R and Houlston RS: Systematic review of microsatellite instability and colorectal cancer prognosis. J Clin Oncol 23(3): 609-618, 2005.

13 Hemminki A, Mecklin JP, Jarvinen H, Aaltonen LA and Joensuu $\mathrm{H}$ : Microsatellite instability is a favorable prognostic indicator in patients with colorectal cancer receiving chemotherapy. Gastroenterology 119(4): 921-928, 2000.

14 Ribas A: Adaptive immune resistance: How cancer protects from immune attack. Cancer Discov 5(9): 915-919, 2015.

15 Campoli $\mathrm{M}$ and Ferrone S: HLA antigen changes in malignant cells: Epigenetic mechanisms and biologic significance. Oncogene 27(45): 5869-5885, 2008.

16 Chang CC and Ferrone S: Immune-selective pressure and HLA class I antigen defects in malignant lesions. Cancer Immunol Immunother 56(2): 227-236, 2007.
17 Iwayama Y, Tsuruma T, Mizuguchi T, Furuhata T, Toyota N, Matsumura M, Torigoe T, Sato N and Hirata K: Prognostic value of hla class i expression in patients with colorectal cancer. World J Surg Oncol 13: 36, 2015.

18 Kitamura H, Honma I, Torigoe T, Asanuma H, Sato N and Tsukamoto T: Down-regulation of HLA class I antigen is an independent prognostic factor for clear cell renal cell carcinoma. J Urol 177(4): 1269-1272, 2007.

19 Homma I, Kitamura H, Torigoe T, Tanaka T, Sato E, Hirohashi Y, Masumori N, Sato N and Tsukamoto T: Human leukocyte antigen class I down-regulation in muscle-invasive bladder cancer: Its association with clinical characteristics and survival after cystectomy. Cancer Sci 100(12): 2331-2334, 2009.

20 Tsukahara T, Kawaguchi S, Torigoe T, Asanuma H, Nakazawa E, Shimozawa K, Nabeta Y, Kimura S, Kaya M, Nagoya S, Wada T, Yamashita $T$ and Sato N: Prognostic significance of HLA class I expression in osteosarcoma defined by anti-pan HLA class I monoclonal antibody, EMR8-5. Cancer Sci 97(12): 1374-1380, 2006.

21 Zaretsky JM, Garcia-Diaz A, Shin DS, Escuin-Ordinas H, Hugo W, Hu-Lieskovan S, Torrejon DY, Abril-Rodriguez G, Sandoval S, Barthly L, Saco J, Homet Moreno B, Mezzadra R, Chmielowski B, Ruchalski K, Shintaku IP, Sanchez PJ, PuigSaus C, Cherry G, Seja E, Kong X, Pang J, Berent-Maoz B, Comin-Anduix B, Graeber TG, Tumeh PC, Schumacher TN, Lo RS and Ribas A: Mutations associated with acquired resistance to PD-1 blockade in melanoma. N Engl J Med 375(9): 819-829, 2016.
Received January 12, 2017

Revised February 22, 2017

Accepted February 24, 2017 